\title{
FORMULATION AND EVALUATION OF FAST DISINTEGRATING LOSARTAN POTASSIUM TABLETS BY FORMAL EXPERIMENTAL DESIGN
}

\author{
Available online at www.ijdra.com
}

\section{RESEARCH ARTICLE}

\author{
Birajdar Shivprasad M*, Bhusnure Omprakash G., Mulaje Suraj S.
}

Department of Quality Assurance, Maharashtra college of Pharmacy, Nilanga, Dist. - Latur,

Maharashtra, India.

*Corresponding Author's E-mail: birajdar100@gmail.com

\begin{abstract}
In the treatment of hypertension fast onset of action is the major concern. The problem of slow onset of action of drugs can be overcome by development of appropriate dosage forms. Fast disintegrating tablets in mouth are best suited and have gained popularity in the oral antihypertensive drug therapy. These are advantageous over other conventional systems in terms of patient compliance, rapid onset of action, accurate dosing, good chemical stability, convenience of self-administration and compactness. Losartan potassium is widely used as an antihypertensive drug, which is a potent drug candidate for developing in to Fast Dissolving Tablets (FDT's). It has low bioavailability due to first pass metabolism. Hence the main objective of the study was to formulate fast dissolving tablets of Losartan potassium to achieve a better dissolution rate and further improving the bioavailability of the drug. Fast dissolving tablet of Losartan potassium were formulated by using microcrystalline cellulose with different concentration of super disintegrants like sodium starch glycolate and Isabgol Mucilage. All the batches were prepared by direct compression. API characterization studies were conducted to check the purity of API .The tablets were evaluated for Pre compression parameters and post compression parameters. Before the formulation of the tablets IR spectroscopic studies were also performed to check the compatibility with the excipients.

A $2^{3}$ full factorial design was applied to investigate the combine effect of 3 formulation variables. Here the concentration of Isabgol mucilage, concentration of Sodium Starch Glycolate and concentration of Microcrystalline Cellulose were taken as independent variable $X_{1}, X_{2} \& X_{3}$ respectively and their effect of disintegration time is studied as dependent parameter. To represent the data Design Expert software is used.
\end{abstract}

Keywords: $2^{3}$ full factorial design; DOE; Fast Dissolving Tablets (FDT’s); Variables.

\section{INTRODUCTION}

The convenience of administration and improved patient compliance are important in the design of oral drug delivery system which remains the preferred route of drug delivery inspite of various disadvantages. One such problem can be solved in the novel drug delivery system by formulating Fast Disintegrating Tablets (FDTs) or "Mouth Disintegrating Tablets" (MDTs) which disintegrates or dissolves rapidly without water within few seconds in the mouth due to the action of superdisintegrant or maximizing pore structure in the formulation. Fast disintegrating tablets are advantageous particularly for pediatric, geriatric and mentally ill patients who have difficulty in swallowing conventional tablets and capsules. The review describes the various formulation aspects, superdisintegrants employed and technologies developed for MDTs, along with various excipients, evaluation tests, marketed formulation and drugs used in this research area.

Losartan potassium approved by the FDA in April 1995, Losartan was launched on that month as the first non-peptide antihypertensive drug in the new class of Ang II receptor antagonists. Merck began selling Losartan under the trade names Cozaar ${ }^{\mathrm{TM}}$ and Hyzaar $^{\mathrm{TM}}$. The two companies DuPont \& Merck shared the revenue. Losartan's new mode of action proved very effective and its selectivity very likely resulted in its fewer side effects. It lacked the dry cough and skin rash that some patients suffered from taking ACE inhibitors. Losartan's metabolite in humans increased its potency and duration, so the drug 
had to be taken only once every 24 hours and it could be taken orally. With a change in its corporate strategy, DuPont exited the pharmaceutical business in 2001.

Formal Experimental Design or DOE is defined as "a structured analysis wherein inputs are changed and differences or variations in outputs are measured to determine the magnitude of the effect of each of the inputs or combination of inputs."

Factorial designs allow for the simultaneous study of the effects that several factors like concentration of superdisintegrants and diluents concentration may have on the physical characteristics of the tablets.

There are several advantages to statistically designed experiments, and when compared with other test methods, the results are striking. One chief reason is that it is strongly favored by regulatory agencies because it justifies the choice of ranges and finds a robust (optimum) region. In addition, it gives the researcher the ability to study interactions between factors. In contrast, merely studying one factor at a time does not allow the researcher to study interactions and is not scalable to production. It provides a more economical use of resources, especially when many factors exist and provides a greater chance of finding optimum conditions. Finally, predictions can be made about future experiments. (1-4)

\section{MATERIALS AND METHOD}

Losartan Potassium was gifted by Dr. Reddy's Lab., Hyderabad and other excipients like Microcrystalline Cellulose (MCC PH102), Talc, Sodium starch glycolate, Mannitol, Magnesium Stearate, Isabgol Seeds are purchased from Research-Lab Fine chem. Industries, Mumbai.

\section{METHOD}

\section{Isolation of Isabgol Mucilage from Isabgol seeds $(5,6)$ :}

Mucilage was isolated by soaking seeds of plantago ovata in water (20-30 times) for at least $48 \mathrm{hrs}$, boiled for $2 \mathrm{hrs}$ subsequently mucilage was released into the water completely. With the help of the muslin cloth the mucilage was squeezed out and separated from seeds. The mucilage collected and precipitated using 3 times of $95 \%$ ethanol. Collected mucilage was dried in the oven at 50$55^{\circ} \mathrm{C}$. Dried mucilage was scraped and powdered using pestle and mortar. Powder was sieved using mesh no.60.

\section{Fourier Transform Infrared Spectro- photometric (FT-IR) study:-}

The IR spectra of previously dried samples were recorded by potassium bromide dispersion technique. 2-3 $\mathrm{mg}$ of sample of drug and excipients were mixed (1:1) with previously dried potassium bromide and kept in sample cell, the cell was then fitted on sample holder and spectrums were recorded.

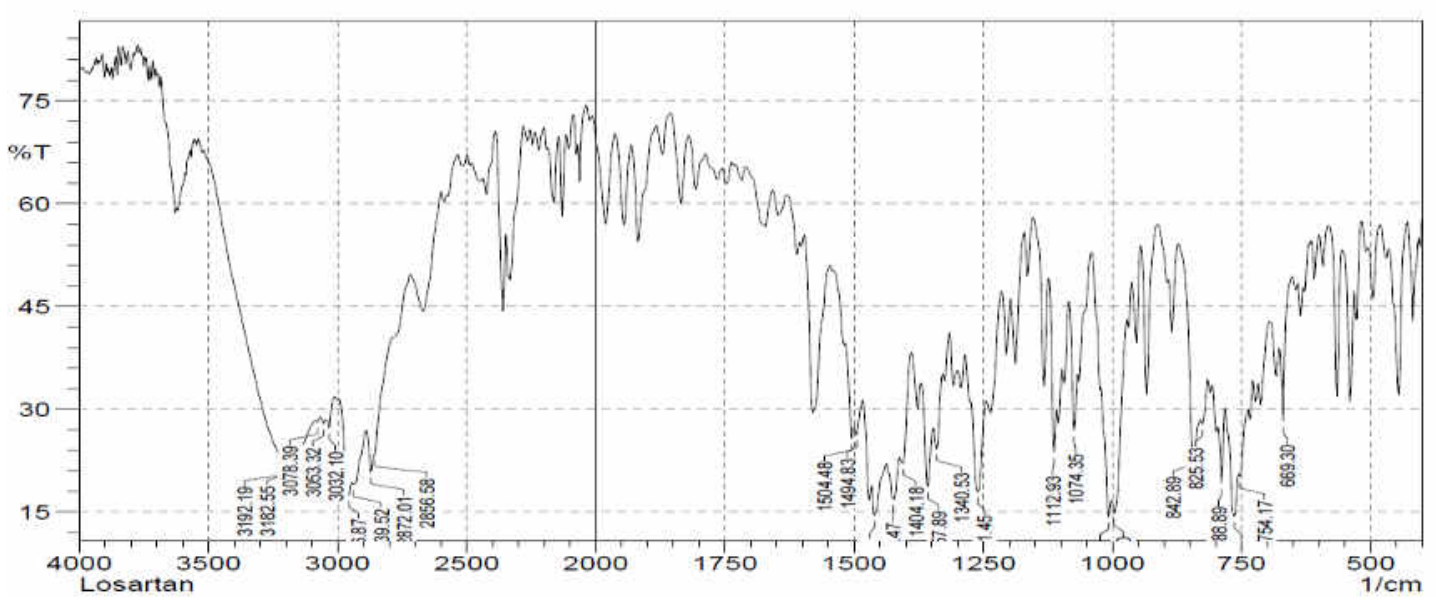

Figure 1: FT-IR spectrum of Losartan potassium 


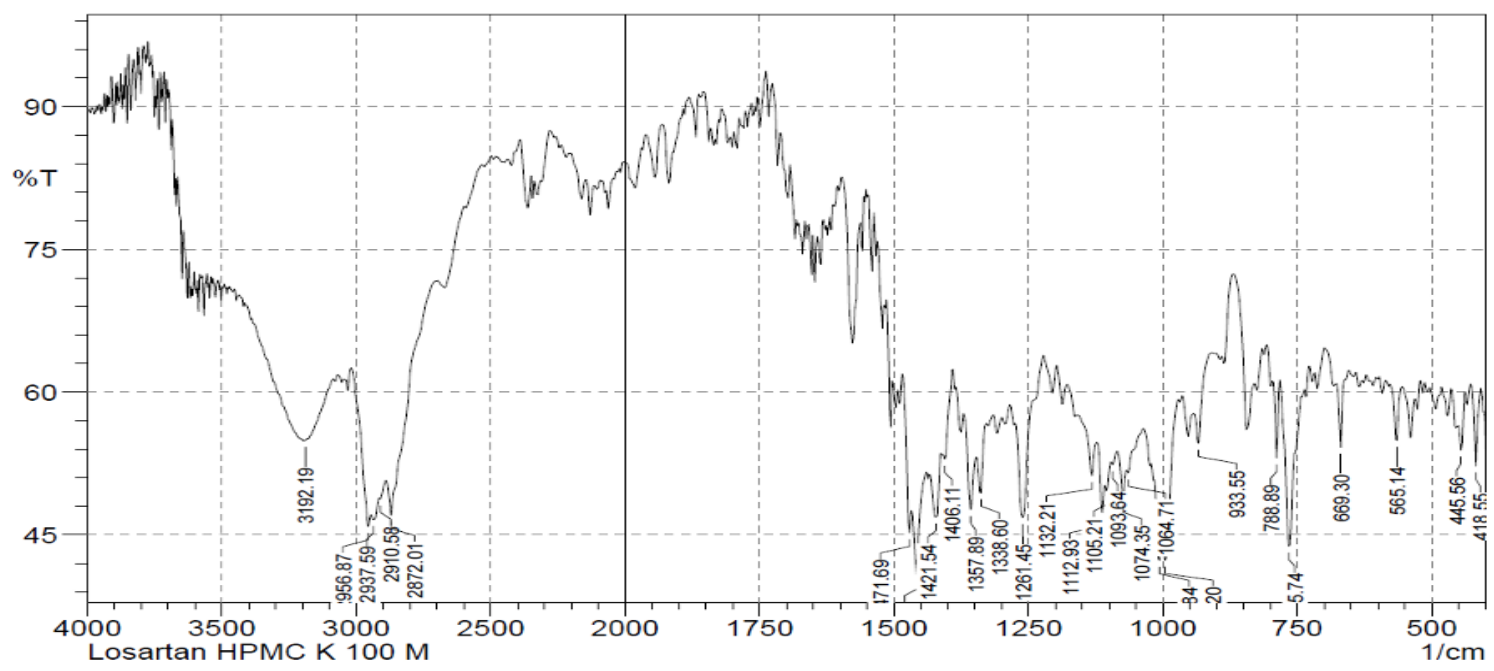

Figure 2: FT-IR spectrum of Losartan potassium \& all excipients

\section{Pre-compression Parameters Study $(7,8)$}

\section{Angle of repose:-}

Angle of repose is defined as the maximum angle possible between the surface of pile of powder and horizontal plane. The angle of repose was calculated by substituting the values of the base radius ' $R$ ' and pile height ' $\mathrm{H}$ ' in the following equation.

$$
\left(=\tan ^{-1} \mathrm{H} / \mathrm{R}\right)
$$

\section{Bulk density:-}

The sample equivalent to $25 \mathrm{~g}$ was accurately weighed and filled in a $100 \mathrm{ml}$ graduated cylinder and the powder was leveled and the unsettled volume, $V_{o}$ was noted. The bulk density was calculated by the formula-

Bulk density $\left(\rho_{\mathrm{o}}\right)=\mathrm{M} / \mathrm{V}_{\mathrm{o}}$

\section{Tapped density:-}

The tapped density was determined by mechanically tapping the measuring cylinder and the volume was noted.

Tapped density $\left(\rho_{t}\right)=\mathrm{M} / \mathrm{V}_{\mathrm{t}}$

\section{Compressibility index:-}

The bulk volume and tapped volume was measured and compressibility index was calculated using the formula.

Compressibility index $=100\left(\mathrm{~V}_{\mathrm{o}}-\mathrm{V}_{\mathrm{f}}\right) / \mathrm{V}_{\mathrm{o}}$

\section{Hausner's ratio:-}

Tapped volume and bulk volume were measured and the hausner's ratio was calculated using the formula

Hausner's ratio $=\mathrm{V}_{\mathrm{o}} / \mathrm{V}_{\mathrm{f}}$

Table 1: Pre-compression Parameters Study

\begin{tabular}{|l|c|l|l|l|l|}
\hline $\begin{array}{c}\text { Formulation } \\
\text { code }\end{array}$ & $\begin{array}{c}\text { Angle of } \\
\text { repose }\end{array}$ & $\begin{array}{c}\text { Bulk } \\
\text { density }\end{array}$ & $\begin{array}{c}\text { Tapped } \\
\text { density }\end{array}$ & $\begin{array}{c}\text { Hausner } \\
\text { ratio }\end{array}$ & $\begin{array}{c}\text { Compressibility } \\
\text { index (\%) }\end{array}$ \\
\hline F1 & $23.29 \pm 0.89$ & $0.58 \pm 0.02$ & $0.68 \pm 0.03$ & $1.129 \pm 0.04$ & $12.76 \pm 0.23$ \\
\hline F2 & $24.61 \pm 1.18$ & $0.54 \pm 0.03$ & $0.65 \pm 0.01$ & $1.178 \pm 0.006$ & $15.15 \pm 0.46$ \\
\hline F3 & $26.41 \pm 0.49$ & $0.57 \pm 0.01$ & $0.69 \pm 0.02$ & $1.185 \pm 0.007$ & $15.63 \pm 0.48$ \\
\hline F4 & $25.10 \pm 0.51$ & $0.59 \pm 0.03$ & $0.69 \pm 0.03$ & $1.103 \pm 0.006$ & $9.39 \pm 0.49$ \\
\hline F5 & $24.31 \pm 0.85$ & $0.61 \pm 0.01$ & $0.72 \pm 0.01$ & $1.125 \pm 0.003$ & $11.60 \pm 1.13$ \\
\hline F6 & $23.44 \pm 1.56$ & $0.58 \pm 0.02$ & $0.69 \pm 0.04$ & $1.098 \pm 0.007$ & $9.02 \pm 0.58$ \\
\hline F7 & $22.55 \pm 0.85$ & $0.58 \pm 0.03$ & $0.71 \pm 0.02$ & $1.170 \pm 0.008$ & $14.57 \pm 0.64$ \\
\hline F8 & $25.02 \pm 0.76$ & $0.55 \pm 0.01$ & $0.66 \pm 0.03$ & $1.129 \pm 0.004$ & $11.92 \pm 0.90$ \\
\hline
\end{tabular}


Preparation of fast dissolving tablets by direct compression technique:

Table 2: Formulations from F1 to F8
Fast dissolving tablets of Losartan potassium were prepared by direct compression method according to the formula.

\begin{tabular}{|l|c|c|c|c|c|c|c|c|}
\hline \multirow{2}{*}{ Ingredients } & \multicolumn{9}{|c|}{ Quantity in 'mg' } \\
\cline { 2 - 9 } & F1 & F2 & F3 & F4 & F5 & F6 & F7 & F8 \\
\hline Losartan potassium & 50 & 50 & 50 & 50 & 50 & 50 & 50 & 50 \\
\hline Isabgol mucilage & 8 & 16 & 8 & 16 & 8 & 16 & 8 & 16 \\
\hline S.S.G. & 8 & 8 & 12 & 12 & 8 & 8 & 12 & 12 \\
\hline M.C.C. & 40 & 40 & 40 & 40 & 60 & 60 & 60 & 60 \\
\hline Magnesium stearate & 1.5 & 1.5 & 1.5 & 1.5 & 1.5 & 1.5 & 1.5 & 1.5 \\
\hline Talc & 1.5 & 1.5 & 1.5 & 1.5 & 1.5 & 1.5 & 1.5 & 1.5 \\
\hline
\end{tabular}

All the ingredients were passed through 60 \# sieve separately, Magnesium stearate \& Talc through $40 \mathrm{\#}$. Then the ingredients were weighed and mixed in geometrical order and tablets were compressed with $8 \mathrm{~mm}$ sizes flat round punch to get tablet using Rimek Compression Machine.

\section{Post-compression Parameters Study (9-15):}

\section{Thickness:}

The thickness of the tablets was determined using a Vernier caliper. Five tablets from each type of formulation were used and average values were calculated. It is expressed in $\mathrm{mm}$.

\section{Hardness:}

The resistance of tablets to shipping, breakage, under conditions of storage, transportation and handling before usage depends on its hardness. For each formulation, the hardness of 6 tablets was determined using the Monsanto hardness tester. The tablet was held along its oblong axis in between the two jaws of the tester. At this point, reading should be zero $\mathrm{kg} / \mathrm{cm}^{2}$. Then constant force was applied by rotating the knob until the tablet fractured. The value at this point was noted.

\section{Friability:}

Friability is the measure of tablet strength.
Roche Friabilator was used for testing the friability using the following procedure. This

test subjects a number of tablets to the combined effect of shock abrasion by utilizing a plastic chamber which revolves at a speed of $25 \mathrm{rpm}$, dropping the tablets to a distance of 6 inches in each revolution. A sample of preweighed 6 tablets was placed in Roche friabilator which was then operated for 100 revolutions i.e. 4 minutes. The tablets were then dusted and reweighed. A loss of less than $1 \%$ in weight in generally considered acceptable. Percent friability ( $\left.\begin{array}{ll}\% & F\end{array}\right)$ was calculated as follows.

\section{Initial weight - Final weight}

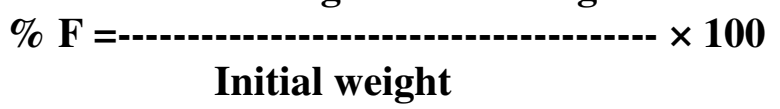

\section{Weight variation test:}

To find out weight variation, 20 tablets of each type of formulation were weighed individually using an electronic balance, average weight was calculated and individual tablet weight was then compared with average value to find the deviation in weight.

\section{Uniformity of drug content:}

Five tablets of each type of formulation were weighed and crushed in mortar and powder equivalent to $50 \mathrm{mg}$ of Losartan potassium was weighed and dissolved in $100 \mathrm{ml}$ of $0.1 \mathrm{~N} \mathrm{HCl}$ 
$(\mathrm{pH}$ 1.2). This was the stock solution from which $0.2 \mathrm{ml}$ sample was withdrawn and diluted to $10 \mathrm{ml}$ with $0.1 \mathrm{~N} \mathrm{HCl}$. The absorbance was measured at wavelength 226 $\mathrm{nm}$ using double beam UV-Visible spectrophotometer.

Content uniformity was calculated using formula -

\% Purity = 10 C (Au / As)

Where, C - Concentration,

$\mathrm{Au}$ and As - Absorbance's obtained from unknown preparation and standard Preparation respectively.

\section{Wetting time:}

The method was applied to measure tablet wetting time. A piece of tissue paper folded twice was placed in a small petri dish (i.d. = $6.5 \mathrm{~cm}$ ) containing $10 \mathrm{ml}$ of water, a tablet was placed on the paper, and the time for complete wetting was measured. Three trials for each batch were performed and standard deviation was also determined.

\section{In vitro disintegration time:}

The process of breakdown of a tablet into smaller particles is called as disintegration. The Table 3: Pre-compression Parameters Study in-vitro disintegration time of a tablet was determined using disintegration test apparatus as per IP specifications.

IP Specifications: Place one tablet in each of the 6 tubes of the basket. Add a disc to each tube and run the apparatus using distilled water maintained at $37( \pm 2(\mathrm{C}$ as the immersion liquid. The assembly should be raised and lowered between 30 cycles per minute in the $\mathrm{pH} 7.4$ maintained at $37( \pm 2$ (C. The time in seconds taken for complete disintegration of the tablet with no palpable mass remaining in the apparatus was measured and recorded.

\section{In vitro dissolution studies:}

Dissolution rate was studied by using USP type-II apparatus (50 rpm) using $900 \mathrm{ml}$ of phosphate buffer $\mathrm{pH}$ (7.4) as dissolution medium. Temperature of the dissolution medium was maintained at $37 \pm 0.5^{\circ} \mathrm{C}$, aliquot of dissolution medium was withdrawn at every 5 min interval and filtered. The absorbance of filtered solution was measured by UV spectrophotometric method at $231 \mathrm{~nm}$ and concentration of the drug was determined from standard calibration curve.

\begin{tabular}{|l|l|l|l|l|}
\hline $\begin{array}{c}\text { Formulation } \\
\text { code }\end{array}$ & \multicolumn{1}{|c|}{$\begin{array}{c}\text { Hardness } \\
\left(\mathbf{k g} / \mathbf{c m}^{2}\right)(\mathbf{S D})\end{array}$} & $\begin{array}{c}\text { Friability } \\
(\%)(\mathbf{S D})\end{array}$ & $\begin{array}{c}\text { Weight variation } \\
(\mathbf{m g})(\mathbf{S D})\end{array}$ & $\begin{array}{c}\text { Thickness } \\
(\mathbf{m m})(\mathbf{S D})\end{array}$ \\
\hline F1 & $3.2 \pm 0.12$ & $0.41(0.03)$ & $201.1(0.05)$ & $3.25 \pm 0.01$ \\
\hline F2 & $2.9 \pm 0.15$ & $0.36(0.05)$ & $200.3(0.02)$ & $3.20 \pm 0.03$ \\
\hline F3 & $2.8 \pm 0.11$ & $0.39(0.06)$ & $200.0(0.03)$ & $3.30 \pm 0.02$ \\
\hline F4 & $2.7 \pm 0.09$ & $0.44(0.04)$ & $200.1(0.06)$ & $3.28 \pm 0.02$ \\
\hline F5 & $3.3 \pm 0.15$ & $0.38(0.08)$ & $201.3(0.08)$ & $3.25 \pm 0.05$ \\
\hline F6 & $3.0 \pm 0.11$ & $0.43(0.09)$ & $199.6(0.09)$ & $3.00 \pm 0.04$ \\
\hline F7 & $3.1 \pm 0.10$ & $0.42(0.03)$ & $200.0(0.03)$ & $3.35 \pm 0.02$ \\
\hline F8 & $2.5 \pm 0.13$ & $0.34(0.08)$ & $202.1(0.05)$ & $3.20 \pm 0.03$ \\
\hline
\end{tabular}

\section{RESULTS \& DISCUSSION}

\section{Hardness:}

The hardness of the tablets prepared was determined by Monsanto Hardness tester and found to be within the range of $2.5 \mathrm{~kg} / \mathrm{cm}^{2}$ to $3.3 \mathrm{~kg} / \mathrm{cm}^{2}$.

Friability test: 
The friability was found in all designed formulations in the range $0.36 \%$ to $0.44 \%$ to be well within the approved range $(<1 \%)$.

\section{Weight variation test:}

The weight variation was found in all designed formulations in the range 199.6 to $202.1 \mathrm{mg}$ and $\%$ deviation was in a range of 0.03 to 1.22. All the tablets passed weight variation test as the average percentage weight variation was within $7.5 \%$ i.e. in the pharmacopoeia limits.

\section{Thickness:}

The mean thickness was $(n=3)$ almost uniform in all the formulations and values ranged from $3.20 \mathrm{~mm}$. to $3.35 \mathrm{~mm}$. The standard deviation values indicated that all the formulations were within the range.

\section{In- vitro disintegration time:}

The in-vitro disintegration time was measured by the time taken to undergo complete In-vitro dissolution study: disintegration. Rapid disintegration within 3 minutes was observed in all the formulations.

The disintegration time of all the formulations is checked $\&$ is found within the range of 46 sec. $-75 \mathrm{sec}$.

\section{Wetting time:}

Wetting time is closely related to the inner structure of the tablet. The wetting time of Losartan potassium tablets prepared were found to be in the range of 34 to $40 \mathrm{sec}$.

\section{Drug Content:}

The drug content uniformity was performed for all the formulations. The average value and standard deviations of all the formulations were calculated. The percentage drugs content of the tablets were found to be between $97.23 \pm 1.26$ to $99.81 \pm 1.84$

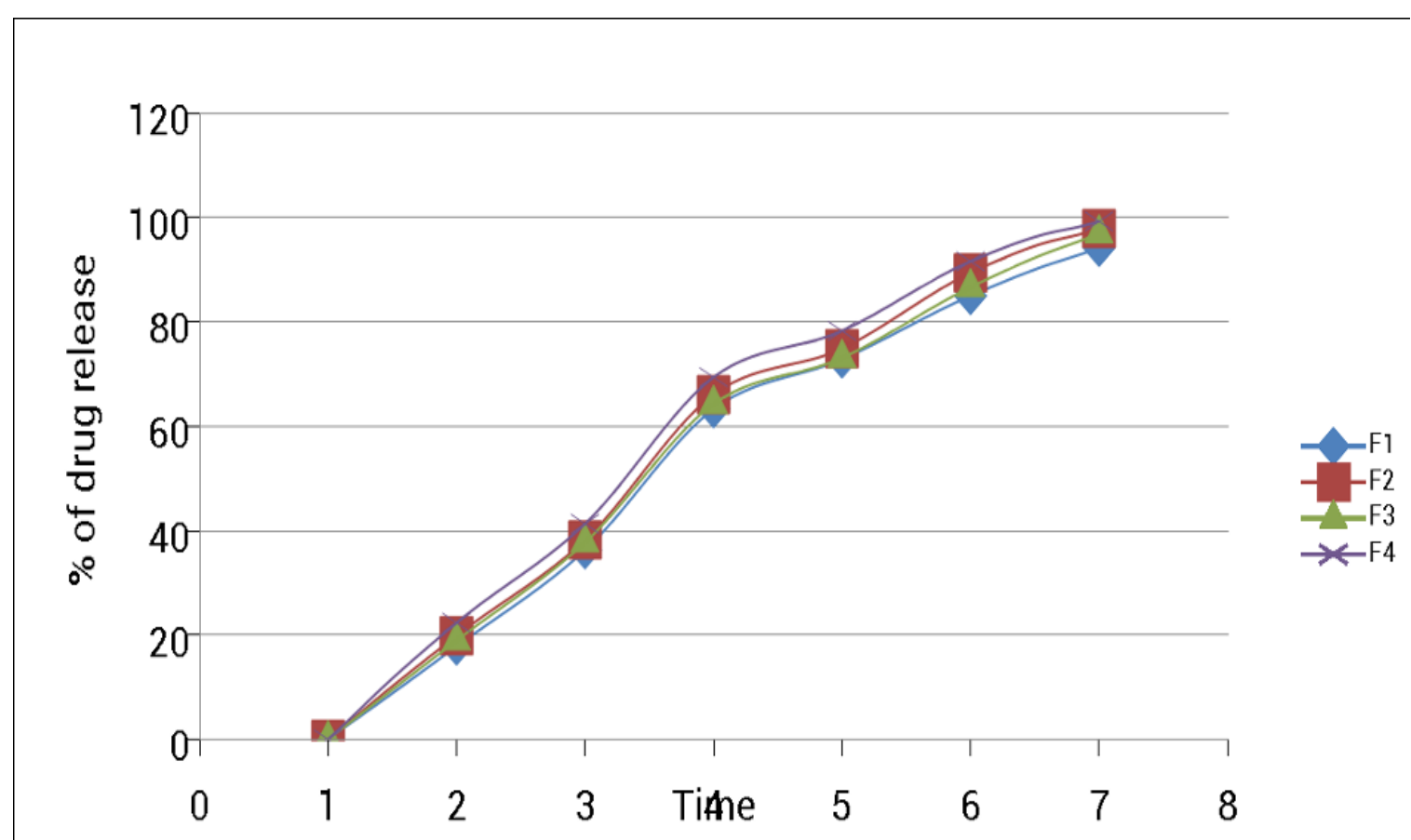

Figure 3: In-vitro dissolution study of batches F1 to F4 


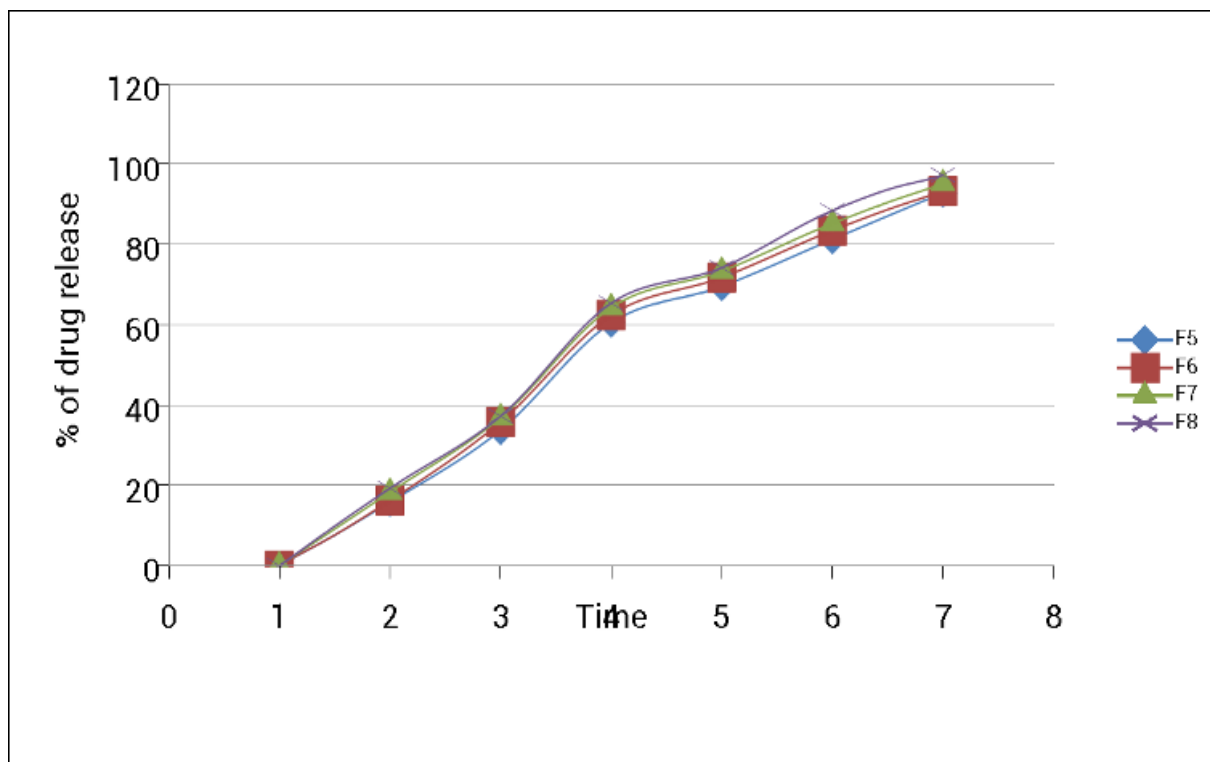

Figure 4: In-vitro dissolution study of batches F5 to F8

Table 4: $2^{3}$ Factorial design with upper $\&$ lower limits of all factors

\begin{tabular}{|l|c|c|}
\hline \multirow{2}{*}{\multicolumn{1}{|c|}{ 3 factors }} & \multicolumn{2}{|c|}{ 2 Levels } \\
\cline { 2 - 3 } & -1 & +1 \\
\hline Conc. of Isabgol mucilage & 8 & 16 \\
\hline Conc. of S.S.G. & 8 & 12 \\
\hline Conc. of M.C.C. & 40 & 60 \\
\hline
\end{tabular}

Statistical Optimization technique (16-21):

The optimization phase was designed statistically using $2^{3}$ factorial design in which three variables namely concentrations of Isabgol mucilage, S.S.G and M.C.C. were kept at two levels. Main interactive influences were tested using statistical methods. The eight formulations of optimization phase were categorized in to four groups for ease of analysis and comparison as follows:

1. Group I: All variables at low level (Formulation F1).

2. Group II: Any one of three variables at high level (Formulations F2, F3 \& F5).

3. Group III: Any two of three variables at high level (Formulations F4, F6, \& F7).

4. Group IV: All three variables at high level (Formulation F8).

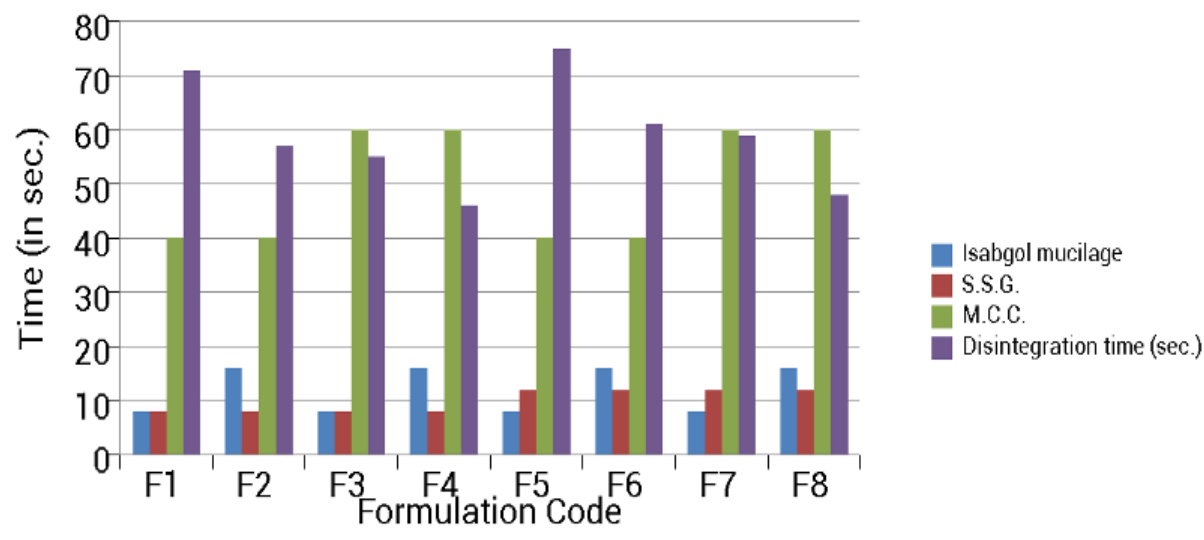

Figure 5: Effect of concentration of Isabgol mucilage, SSG \& MCC 
Although all formulation were analyzed for disintegration time, amount of drug release at the end of 30 minutes, and mechanism of drug release, and all of these parameters were considered for selection of best formulation in the optimization phase.

\section{Main Effects}

Effect of Isabgol mucilage $=((\mathrm{Y} 2-\mathrm{Y} 1)+(\mathrm{Y} 4-$ Y3) + (Y6-Y5) + (Y8-Y7) / 4

$=((57-71)+(46-55)+(61-75)+(48-59) / 4$

$=-12$

Effect of SSG $=((\mathrm{Y} 3-\mathrm{Y} 1)+(\mathrm{Y} 4-\mathrm{Y} 2)+(\mathrm{Y} 7-$ $\mathrm{Y} 5)+(\mathrm{Y} 8-\mathrm{Y} 6)) / 4$

$=((55-71)+(46-57)+(59-75)+(48-61)) / 4$

$=-14$

Effect of $\mathrm{MCC}=((\mathrm{Y} 5-\mathrm{Y} 1)+(\mathrm{Y} 6-\mathrm{Y} 2)+(\mathrm{Y} 7-$ $\mathrm{Y} 3)+(\mathrm{Y} 8-\mathrm{Y} 4)) / 4$

$=((75-71)+(61-57)+(59-55)+(48-46)) / 4$ $=+3.50$

\section{Effect of Isabgol mucilage \& SSG:}

High level $(+)=((\mathrm{Y} 4-\mathrm{Y} 3)+(\mathrm{Y} 8-\mathrm{Y} 7)) / 2$

$$
\begin{aligned}
& =((46-55)+(48-59)) / 2 \\
& =-10
\end{aligned}
$$

Low level $(-)=((\mathrm{Y} 2-\mathrm{Y} 1)+(\mathrm{Y} 6-\mathrm{Y} 5)) / 2$

$$
\begin{aligned}
& =((57-71)+(61-75)) / 2 \\
& =-14
\end{aligned}
$$

\section{Effect of Isabgol mucilage \& MCC:}

$$
\begin{aligned}
& \text { High level }=((\mathrm{Y} 8-\mathrm{Y} 4)+(\mathrm{Y} 7-\mathrm{Y} 3)) / 2 \\
& =((48-46)+(59-55)) / 2 \\
& =3 \\
& =((61-57)+(75-71)) / 2 \\
& =4
\end{aligned}
$$

\section{Effect of MCC \& SSG:}

High level $=((\mathrm{Y} 6-\mathrm{Y} 2)+(\mathrm{Y} 8-\mathrm{Y} 4)) / 2$

$$
\begin{aligned}
& =((61-57)+(48-46)) / 2 \\
& =3
\end{aligned}
$$

Low level $=((\mathrm{Y} 5-\mathrm{Y} 1)+(\mathrm{Y} 7-\mathrm{Y} 3)) / 2$

$$
\begin{aligned}
& =((75-71)+(59-55)) / 2 \\
& =4
\end{aligned}
$$

\section{Effect of Isabgol mucilage, SSG \& MCC:}

\section{Calculation of coefficient}

$$
\text { B0 }=((1) x(Y 1)+(1) x(Y 2)+(1) x(Y 3)+(1) x(Y 4)+(1) x(Y 5)+(1) x(Y 6)+(1) x(Y 7)+(1) x(Y 8)) / 8
$$

\begin{tabular}{|l|l|}
\hline \multicolumn{1}{|c|}{ Effect } & Estimate \\
\hline Main Effects & -12 \\
\hline Effect Of Isabgol Mucilage & -14 \\
\hline Effect Of SSG & +3.5 \\
\hline Effect Of MCC & -12 \\
\hline Two Factor Interactions & -0.5 \\
\hline Isabgol Mucilage \& SSG & -0.5 \\
\hline Isabgol Mucilage \& MCC \\
\hline MCC \& SSG \\
\hline Three Factor Interactions \\
\hline Isabgol Mucilage,SSG \& MCC & -12 \\
\hline
\end{tabular}

High level $=((\mathrm{Y} 8-\mathrm{Y} 7)+(\mathrm{Y} 6-\mathrm{Y} 5)) / 2$

$$
\begin{aligned}
& =((48-59)+(61-75)) / 2 \\
& =-12.5
\end{aligned}
$$

Low level $=((\mathrm{Y} 4-\mathrm{Y} 3)+(\mathrm{Y} 2-\mathrm{Y} 1)) / 2$

$$
\begin{aligned}
& =((46-55)+(57-71)) / 2 \\
& =-11.5
\end{aligned}
$$

Isabgol mucilage $x$ SSG $=1 / 2$ difference

$=($ High level - low level $) / 2$

$=[(-10)-(-14)] / 2$

$=-12$

Isabgol mucilage $\times$ MCC $=\mathbf{1 / 2}$ difference

$=($ High level - low level $) / 2$

$=(3-4) / 2=-0.5$

\section{MCC x SSG $=1 / 2$ difference}

$=($ High level - low level $) / 2$

$=(3-4) / 2$

$=-0.5$

Isabgol mucilage $x$ SSG $x$ MCC $=1 / 2$ difference

$=($ High level - low level $) / 2$

$=[(-12.5)-(-11.5)] / 2$

$=-12$

All these interpretations and implications of disintegrants characteristics over release profile were supported statistically and the results of main effects, interactive (two and three way) effects, were enlisted in Table.

Table 5: Effects and their average estimates in the formulation 
$=((1 \times 71)+(1 \times 57)+(1 \times 55)+(1 \times 46)+(1 \times 75)+(1 \times 61)+(1 \times 59)+(1 \times 48)) / 8$

$=59$

$\mathbf{B 1}=((-1) \mathrm{x}(\mathrm{Y} 1)+(1) \mathrm{x}(\mathrm{Y} 2)+(-1) \mathrm{x}(\mathrm{Y} 3)+(1) \mathrm{x}(\mathrm{Y} 4)+(-1) \mathrm{x}(\mathrm{Y} 5)+(1) \mathrm{x}(\mathrm{Y} 6)+(-1) \mathrm{x}(\mathrm{Y} 7)+(1) \mathrm{x}(\mathrm{Y} 8)) / 8$

$=\{(-1) \mathrm{x}(71)+(1) \mathrm{x}(57)+(-1) \mathrm{x}(55)+(1) \mathrm{x}(46)+(-1) \mathrm{x}(75)+(1) \mathrm{x}(61)+(-1) \mathrm{x}(59)+(1) \mathrm{x}(48)\} / 8$

$=-6$

$\mathbf{B 2}=((-1) \mathrm{x}(\mathrm{Y} 1)+(-1) \mathrm{x}(\mathrm{Y} 2)+(1) \mathrm{x}(\mathrm{Y} 3)+(1) \mathrm{x}(\mathrm{Y} 4)+(-1) \mathrm{x}(\mathrm{Y} 5)+(-1) \mathrm{x}(\mathrm{Y} 6)+(1) \mathrm{x}(\mathrm{Y} 7)+(1) \mathrm{x}(\mathrm{Y} 8)) / 8$ $=((-1) \times(71)+(-1) x(57)+(1) \times(55)+(1) x(46)+(-1) \times(75)+(-1) x(61)+(1) x(59)+(1) x(48)) / 8$ $=-7$

$\mathbf{B 3}=((-1) \mathrm{x}(\mathrm{Y} 1)+(-1) \mathrm{x}(\mathrm{Y} 2)+(-1) \mathrm{x}(\mathrm{Y} 3)+(-1) \mathrm{x}(\mathrm{Y} 4)+(1) \mathrm{x}(\mathrm{Y} 5)+(1) \mathrm{X}(\mathrm{Y} 6)+(1) \mathrm{x}(\mathrm{Y} 7)+(1) \mathrm{x}(\mathrm{Y} 8)) / 8$ $=((-1) \mathrm{x}(71)+(-1) \mathrm{x}(57)+(-1) \mathrm{x}(55)+(-1) \mathrm{x}(46)+(1) \mathrm{x}(75)+(1) \mathrm{X}(61)+(1) \mathrm{x}(59)+(1) \mathrm{x}(48)) / 8$ $=1.75$

$\mathbf{B 1 2}=((1) \mathrm{x}(\mathrm{Y} 1)+(-1) \mathrm{x}(\mathrm{Y} 2)+(-1) \mathrm{x}(\mathrm{Y} 3)+(1) \mathrm{x}(\mathrm{Y} 4)+(1) \mathrm{x}(\mathrm{Y} 5)+(-1) \mathrm{x}(\mathrm{Y} 6)+(-1) \mathrm{x}(\mathrm{Y} 7)+(1) \mathrm{x}(\mathrm{Y} 8)) / 8$ $=((1) \mathrm{x}(71)+(-1) \mathrm{x}(57)+(-1) \mathrm{x}(55)+(1) \mathrm{x}(46)+(1) \mathrm{x}(75)+(-1) \mathrm{x}(61)+(-1) \mathrm{x}(59)+(1) \mathrm{x}(48)) / 8$ $=1$

$\mathbf{B 1 3}=((1) \mathrm{x}(\mathrm{Y} 1)+(-1) \mathrm{x}(\mathrm{Y} 2)+(1) \mathrm{x}(\mathrm{Y} 3)+(-1) \mathrm{x}(\mathrm{Y} 4)+(-1) \mathrm{x}(\mathrm{Y} 5)+(1) \mathrm{x}(\mathrm{Y} 6)+(-1) \mathrm{x}(\mathrm{Y} 7)+(1) \mathrm{x}(\mathrm{Y} 8)) / 8$ $=((1) \times(71)+(-1) \times(57)+(1) \times(55)+(-1) \times(46)+(-1) \times(75)+(1) \times(61)+(1) \times(59)+(1) \times(48)) / 8$ $=-0.25$

$\mathbf{B 2 3}=((1) \mathrm{x}(\mathrm{Y} 1)+(1) \mathrm{x}(\mathrm{Y} 2)+(-1) \mathrm{x}(\mathrm{Y} 3)+(-1) \mathrm{x}(\mathrm{Y} 4)+(-1) \mathrm{x}(\mathrm{Y} 5)+(-1) \mathrm{x}(\mathrm{Y} 6)+(1) \mathrm{x}(\mathrm{Y} 7)+(1) \mathrm{x}(\mathrm{Y} 8)) / 8$ $=((1) \times(71)+(1) \times(57)+(-1) \times(55)+(-1) \times(46)+(-1) \times(75)+(-1) x(61)+(1) \times(59)+(1) \times(48)) / 8$ $=-0.25$

B123 $=((-1) x(Y 1)+(1) x(Y 2)+(1) x(Y 3)+(-1) x(Y 4)+(1) x(Y 5)+(1) x(Y 6)+(1) x(Y 7)+(1) x(Y 8)) / 8$ $=((-1) \times(71)+(1) \times(57)+(1) \times(55)+(-1) \times(46)+(1) \times(75)+(1) \times(61)+(1) \times(59)+(1) \times(48)) / 8$ $=29.75$

\section{Apply the above values in the basic polynomial equation.}

Let us consider transformed values

$\mathrm{x} 1=0.5$

$\mathrm{x} 2=0.5$

$\mathrm{x} 3=0.5$

\section{Actual polynomial Equation}

$\mathrm{Y}=\mathrm{B}_{0}+\mathrm{B}_{1} \mathrm{X}_{1}+\mathrm{B}_{2} \mathrm{X}_{2}+\mathrm{B}_{3} \mathrm{X}_{3}+\mathrm{B}_{12}\left(\mathrm{X}_{1} \mathrm{X}_{2}\right)+\mathrm{B}_{13}\left(\mathrm{X}_{1} \mathrm{X}_{3}\right)+\mathrm{B}_{23}\left(\mathrm{X}_{2} \mathrm{X}_{3}\right)+\mathrm{B}_{123}\left(\mathrm{X}_{1} \mathrm{X}_{2} \mathrm{X}_{3}\right)$ $\mathrm{Y}=59+[(-6) 0.5]+[(-7) 0.5]+[1.75(0.5)]+[1(0.5)(0.5)]+[(-0.25)(0.5)(0.5)]+[(-0.25)(0.5)(0.5)]+$ $[29.75(0.5)(0.5)(0.5)]$

$=47.2187$ 


\section{Response surface methodology:}
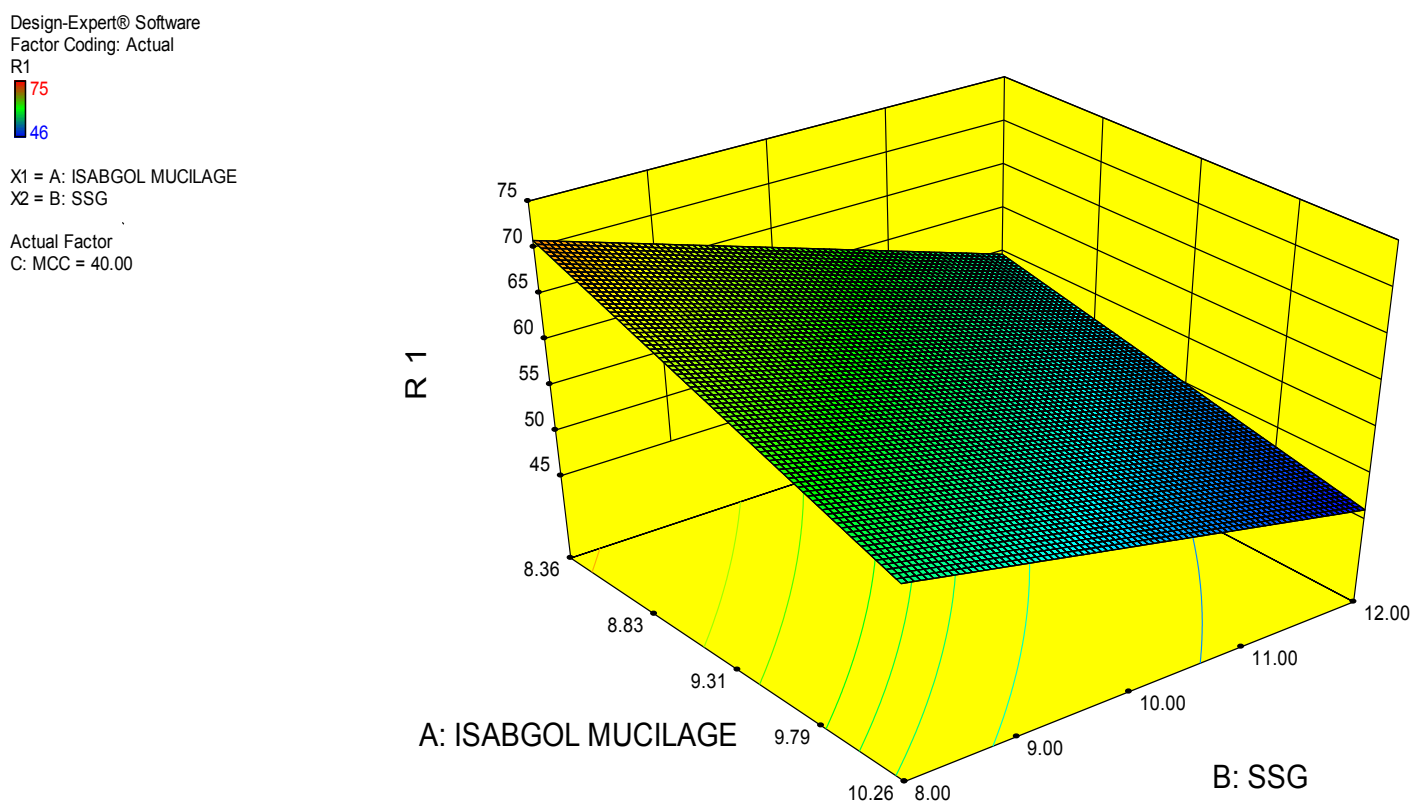

Figure 6: Response surface diagram showing combined effect of Isabgol mucilage \& SSG when MCC kept at lower level i.e.40 mg.
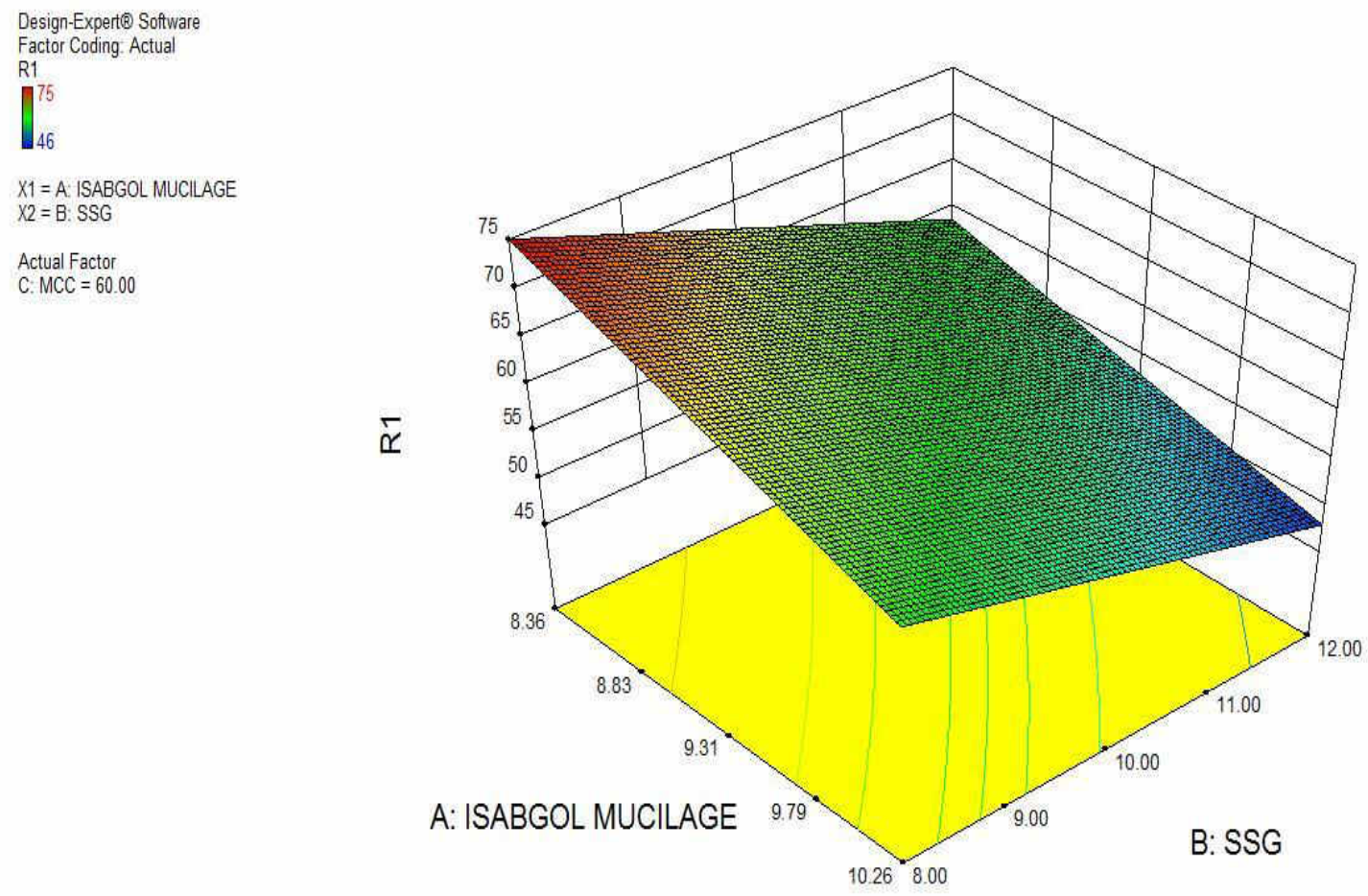

Figure 7: Response surface diagram showing combined effect of Isabgol mucilage \& SSG when MCC kept at higher level i.e.60 mg. 
Design-Expert(8) Software

Factor Coding. Actual

$R 1$
$\prod_{46}^{75}$

$X 1=B: S S G$

$X 2=C: M C C$

Actual Factor

A: ISABGOL MUCILAGE $=8.00$

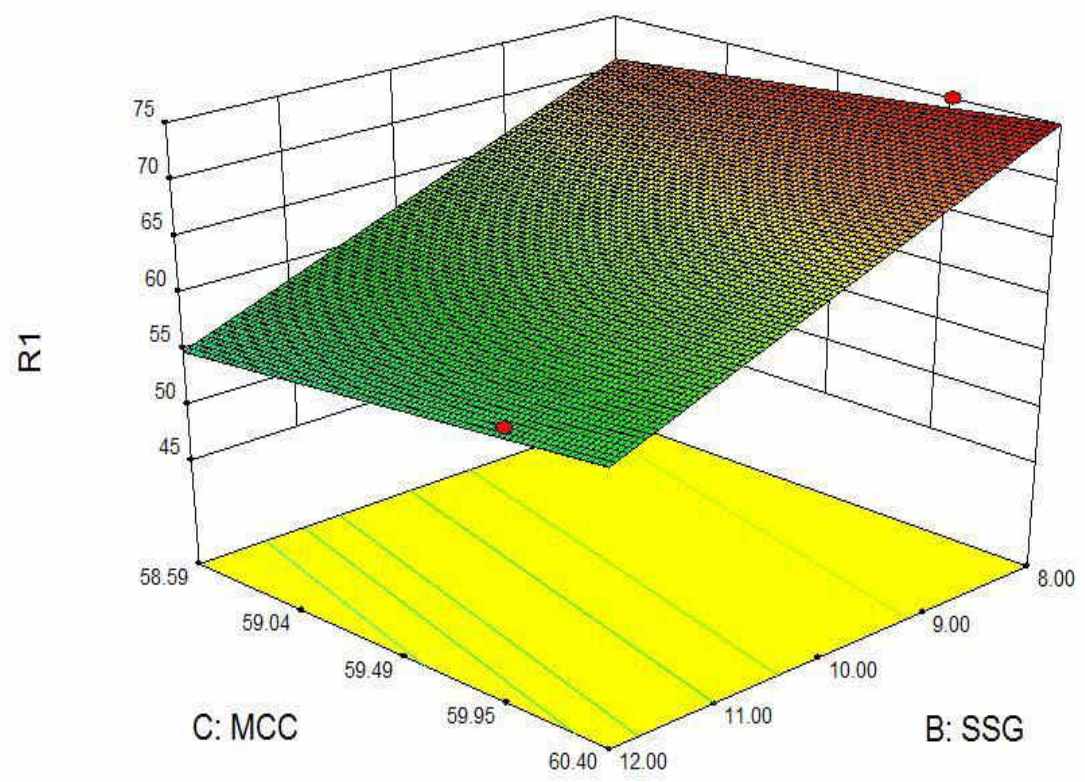

Figure 8: Response surface diagram showing Combined effect of MCC \& SSG when Isabgol Mucilage kept at lower level i.e. $8 \mathrm{mg}$.

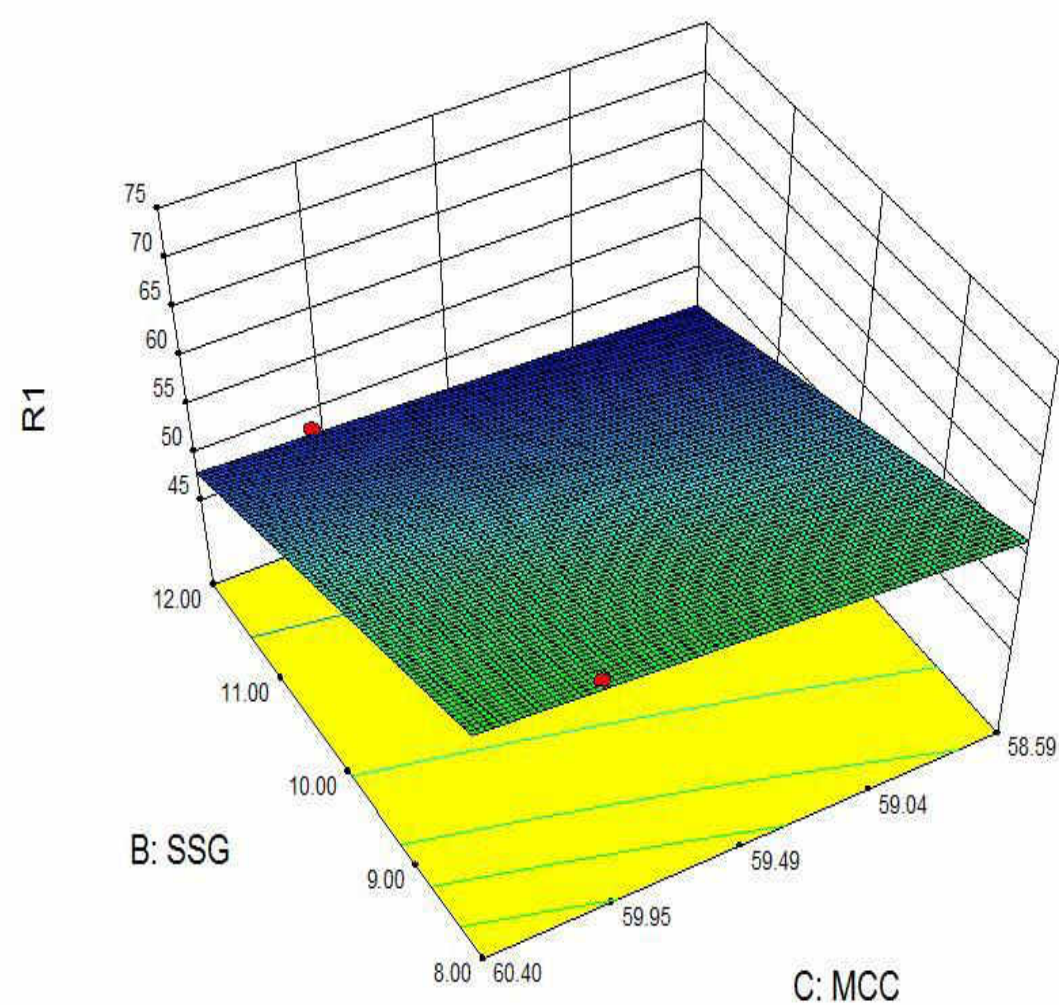

Figure 9: Response surface diagram showing Combined effect of MCC \& SSG when Isabgol Mucilage kept at higher level i.e. 16mg. 
Design-Expert(8) Software

Factor Coding: Actual

R1

46

$X_{1}=A \cdot I S A B G O L$ MUCILAGE

$X 2=C \cdot M C C$

Actual Factor

B. $S S G=8.00$

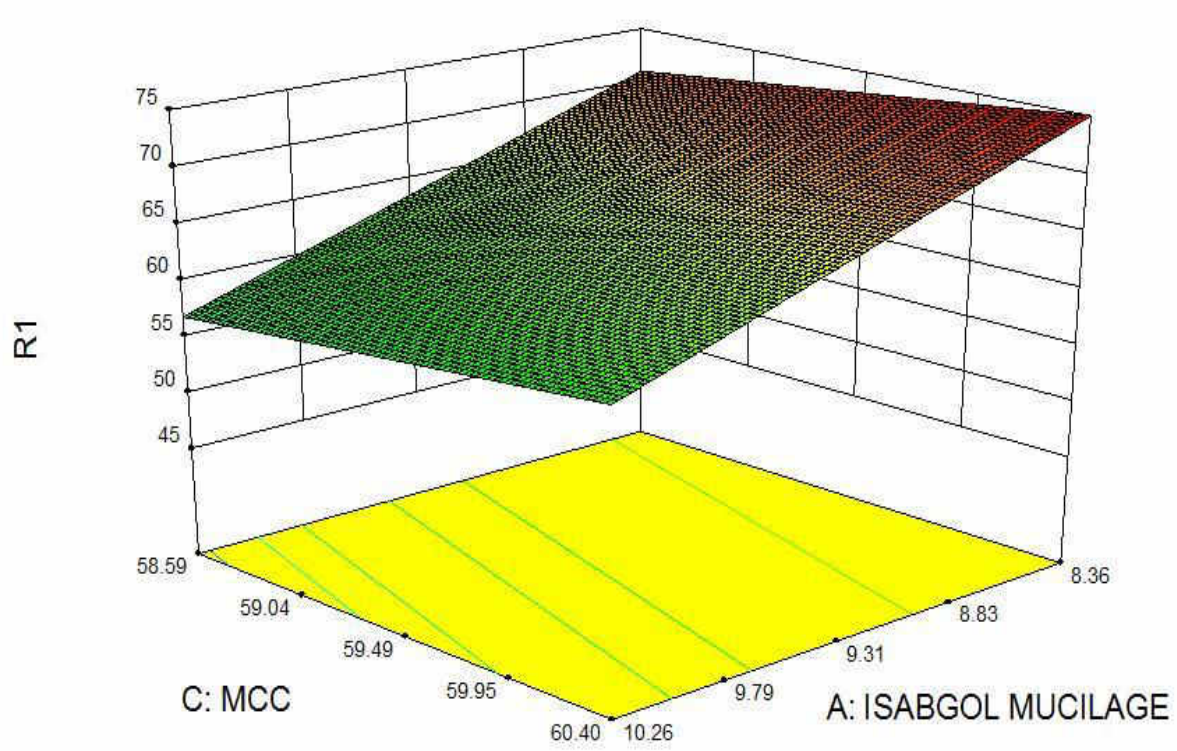

Figure 10: Response surface diagram showing Combined effect of MCC \& Isabgol Mucilage when SSG kept at lower level i.e. $8 \mathrm{mg}$.
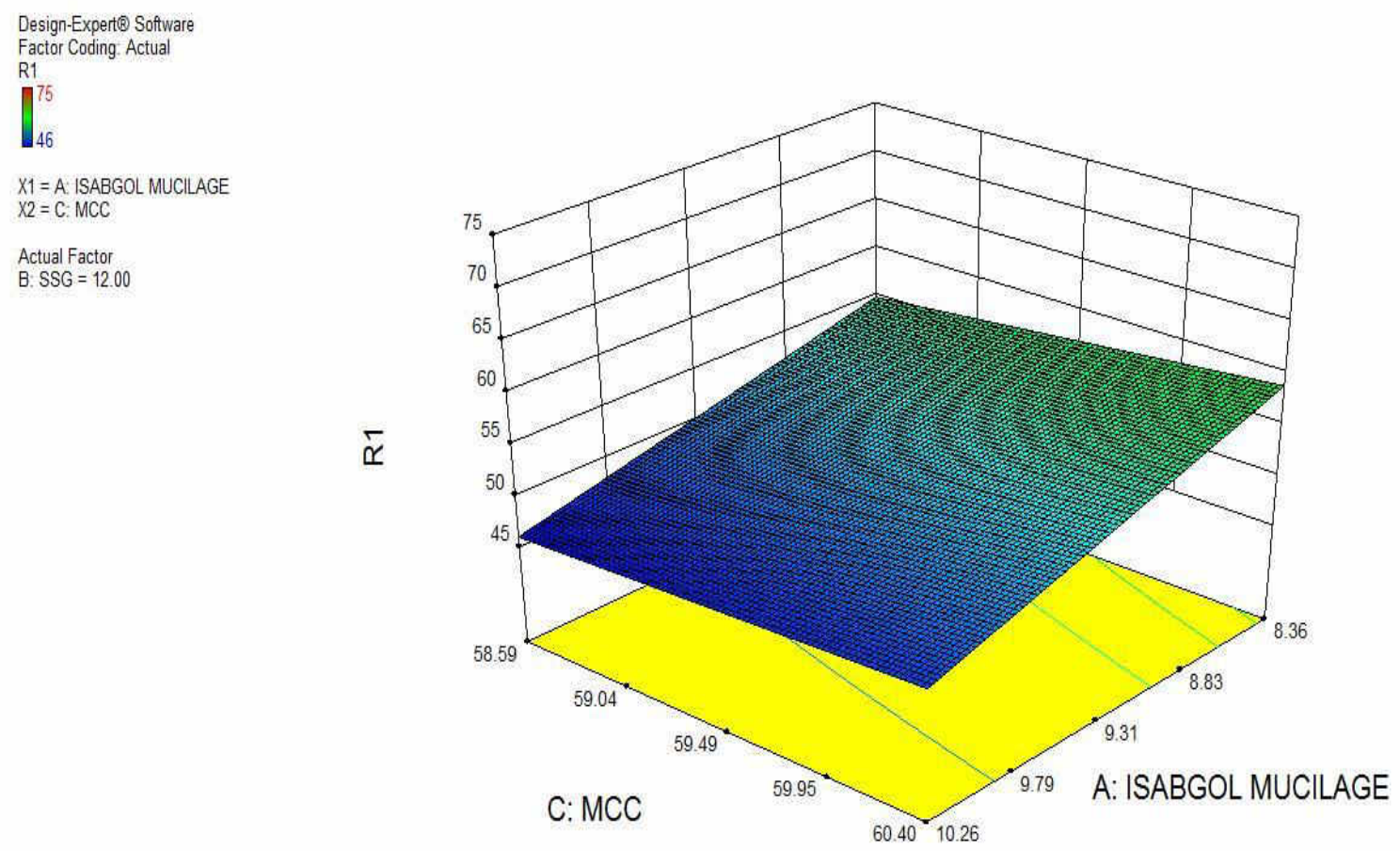

Figure 11: Response surface diagram showing Combined effect of MCC \& Isabgol Mucilage when SSG kept at lower level i.e. $8 \mathrm{mg}$. 


\section{Contour plots:}

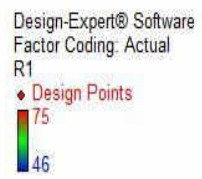

$X 1=A: I S A B G O L$ MUCLLAGE $X 2=B: S S G$

Actual Factor

C: $M C C=40.00$

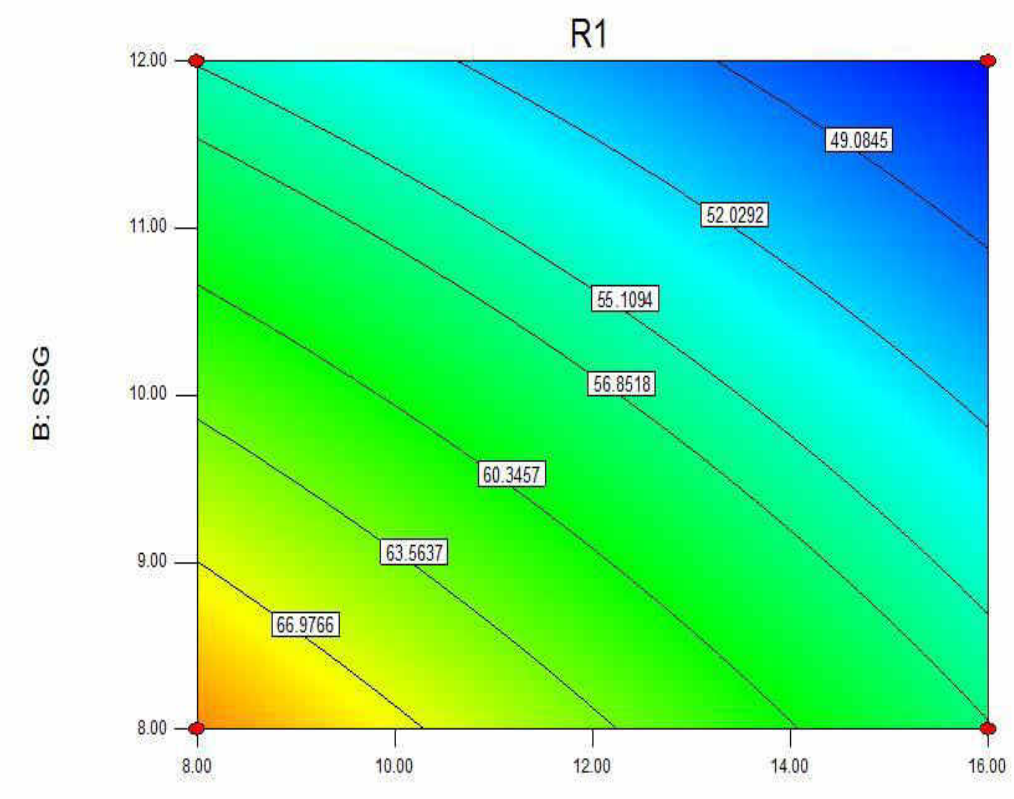

A: ISABGOL MUCILAGE

Figure 12: Contour plot showing combined effect of Isabgol mucilage \& SSG when MCC kept at lower level i.e.40 mg.
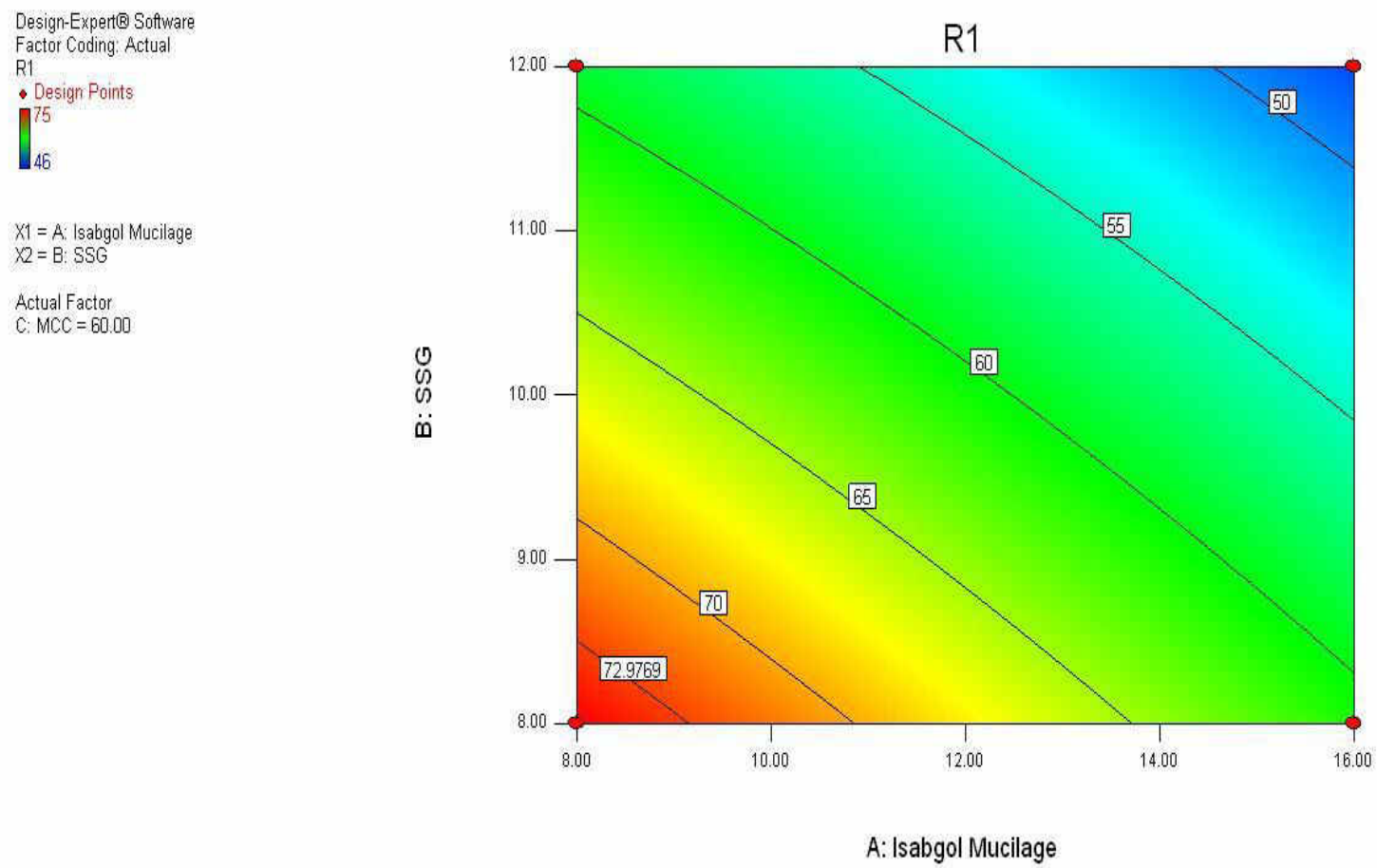

Figure 13: Contour plot showing combined effect of Isabgol mucilage \& SSG when MCC kept at higher level i.e. $60 \mathrm{mg}$. 

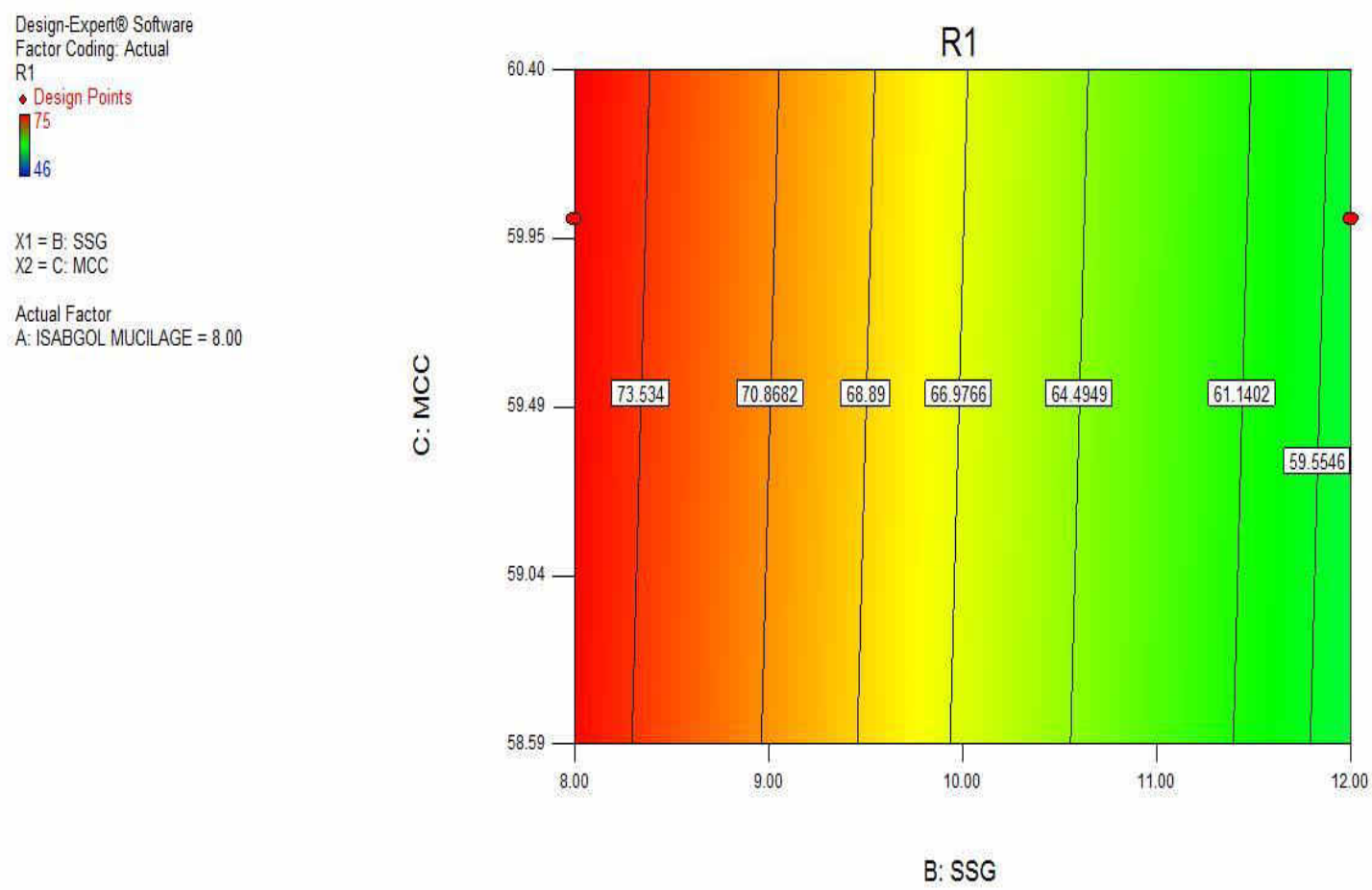

Figure 14: Contour plot showing Combined effect of MCC \& SSG when Isabgol Mucilage kept at lower level i.e. $8 \mathrm{mg}$.
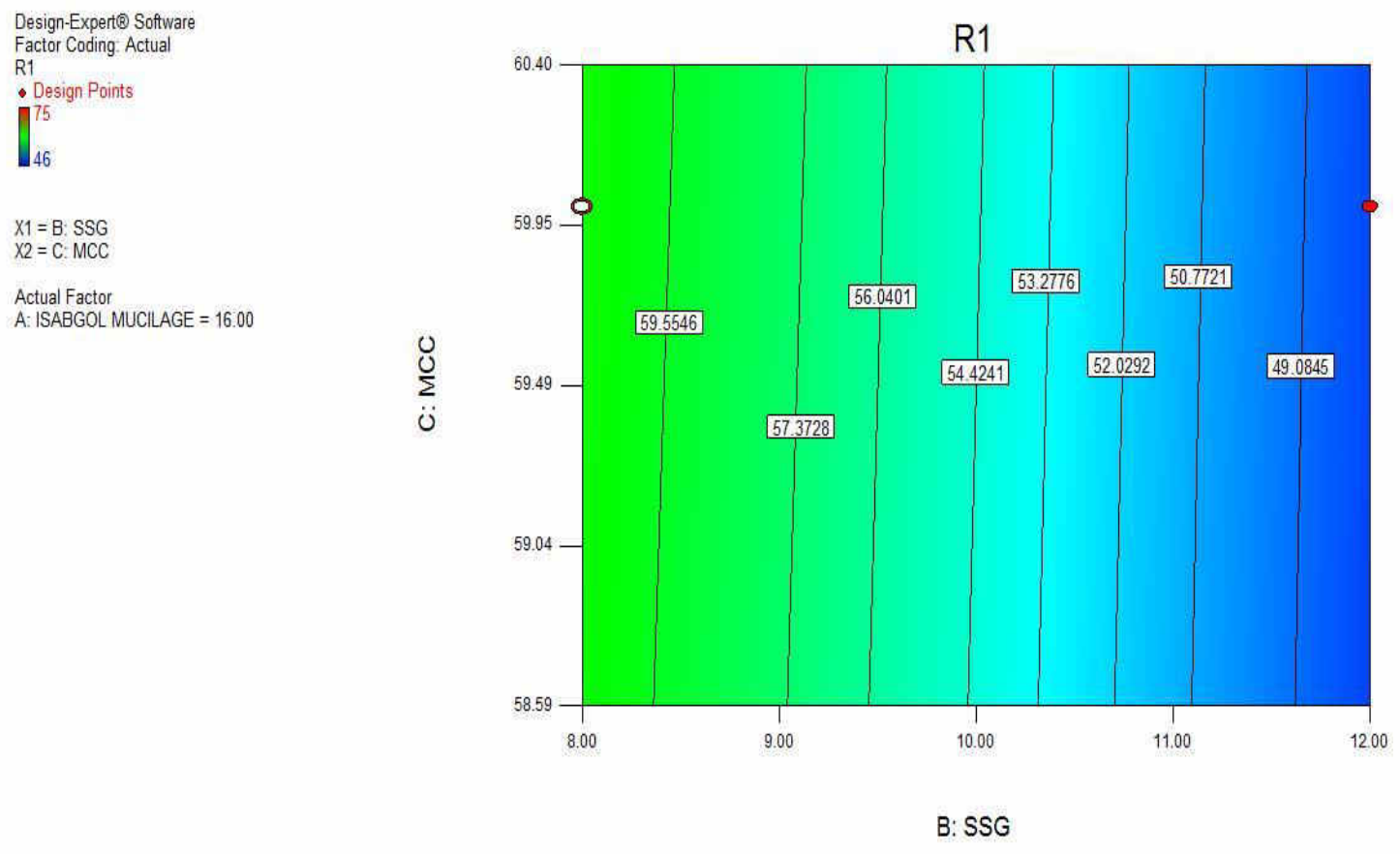

Figure 15: Contour plot showing Combined effect of MCC \& SSG when Isabgol Mucilage kept at higher level i.e. $16 \mathrm{mg}$. 
Design:Expertiø Software Factor Coding: Actual

R1

- Design Points

$\prod_{46}^{75}$

$X_{1}=A:$ ISABGOL MUCLLAGE

$X_{2}=C: M C C$

Actual Factor

B: $S S G=8.00$

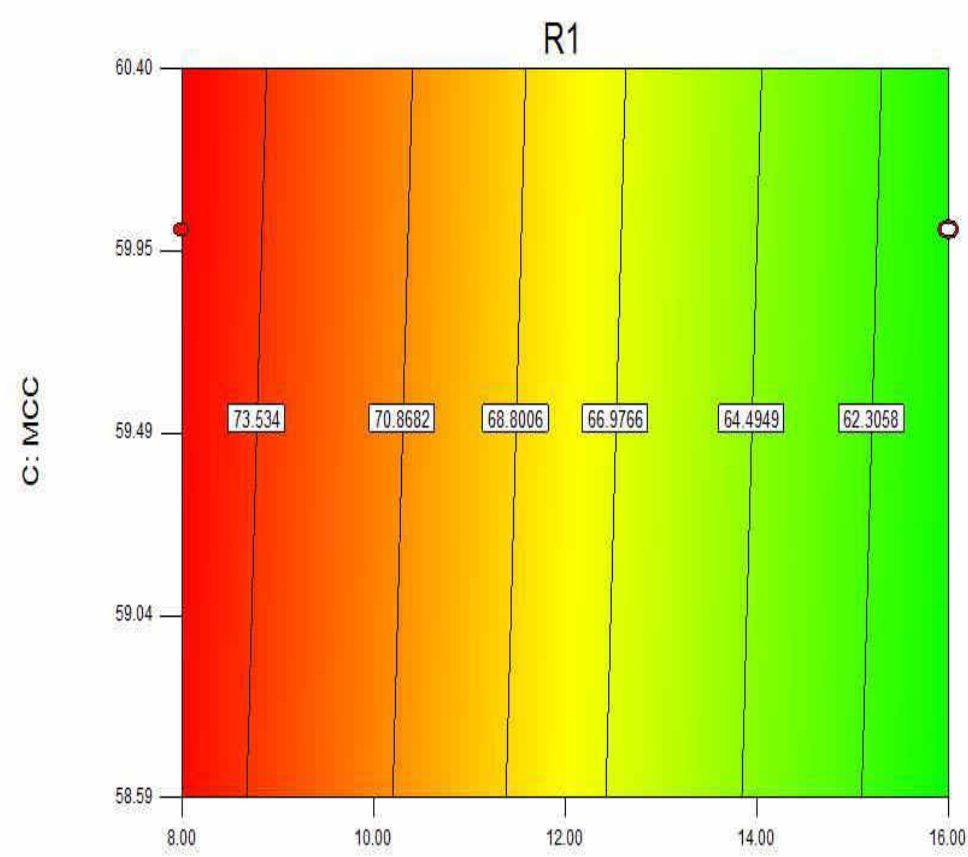

A: ISABGOL MUCILAGE

Figure 16: Contour plot showing Combined effect of MCC \& Isabgol Mucilage when SSG kept at lower level i.e. $8 \mathrm{mg}$.
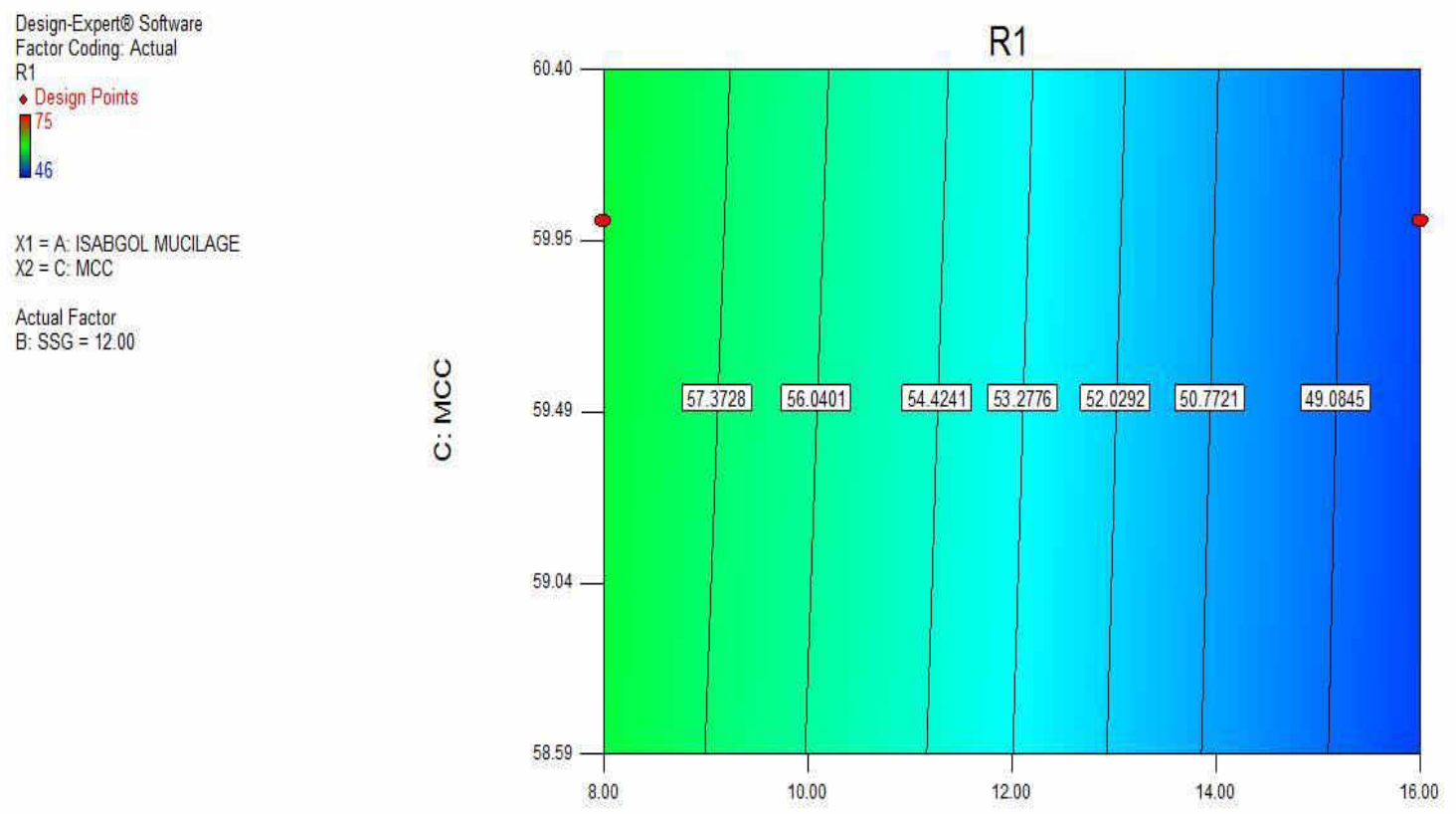

A: ISABGOL MUCILAGE

Figure 17: Contour plot showing Combined effect of MCC \& Isabgol Mucilage when SSG kept at higher level i.e. $12 \mathrm{mg}$. 


\section{CONCLUSION}

In present work, a fast disintegrating Losartan potassium tablets were developed. Losartan potassium was selected for this investigation because the absorption window of this drug is the upper part of small intestine Step by step studies were carried out to develop and optimize oral fast disintegrating tablet for Losartan potassium using natural \& semi synthetic superdisintegrants.

In the preliminary part, FT-IR study was carried out which suggested that there was no significant drug interaction between Losartan potassium with superdisintegrants and other excipients. UV scan of Losartan potassium had shown maximum absorption at wavelength 226 $\mathrm{nm}$ in $0.1 \mathrm{~N} \mathrm{HCl}$. Physical parameters like hardness, weight variation, thickness and friability were within Pharmacopoeial limit. Percentage drug content in all tablet formulations was found within Pharmacopoeial limit.

The disintegration time of all the formulations from F1 to F8 was found within the limit 46 to $75 \mathrm{sec}$.

The negative value in the table no.05 indicates that the increase in concentration of that particular Excipients retards the disintegration time. The same value i.e. -12 for the two factor interactions (Isabgol mucilage \& SSG) \& three factor interactions (Isabgol Mucilage, SSG \& MCC) indicates that the disintegration caused due to both superdisintegrants Isabgol mucilage \& SSG is unaffected by the use of MCC.

The in-vitro disintegration time of tablets prepared by direct compression method were found to be in the range of 46 to $75 \mathrm{sec}$. Formulation VS4 showed in-vitro disintegration time $46 \mathrm{Sec}$. Based on the invitro disintegration time, Promising formulations $\mathrm{F} 4$, which facilitate the faster disintegration in the mouth. Hence, finally it was concluded that the prepared fast dissolving tablets of Losartan potassium may prove to be potential candidate for safe and effective fast disintegrating tablet dosage form by Formal Experimental Design method.

Hence, finally it was concluded that the prepared fast dissolving tablets of Losartan potassium may prove to be potential candidate for safe and effective fast disintegrating tablet dosage form by Formal Experimental Design method.

\section{ACKNOWLEDGEMENTS}

The authors are thankful to Dr. Reddy's Lab., Hyderabad \& Research-Lab Fine chem. Industries, Mumbai for providing gift samples of API \& other excipients respectively. The authors are also thankful to Principal, Maharashtra College of Pharmacy, Nilanga for providing necessary facility for the work.

\section{CONFLICT OF INTEREST}

Author declares that there are no conflict of interest.

\section{REFERENCES}

1. Lachman L, Lieberman H.A., Kanig J.L. The theory and practice of industrial pharmacy. $3^{\text {rd }}$ edition. Mumbai: Varghese Publishing House; 1987. p. 182-84.

2. Staniforth J.N., Aulton M.E. Powder flow In: Alton's Pharmaceutics. The design and manufacturing of medicines. $3^{\text {rd }}$ ed. Hungary: Harcourt publisher Ltd. ; 2007. P. 175-79.

3. Ansel H.C., Popovich NG, Allen LV. Pharmaceutical dosage forms and drug delivery system. $8^{\text {th }}$ ed. New Delhi: B. I. Waverly Pvt. Ltd.; 1995. p.189-94, 235-36.

4. Martin A. Diffusion and Dissolution. In: Physical pharmacy. $3^{\text {rd }}$ ed. Philadelphia: Lea and Febiger; 1983.p.399-444.

5. Pahwa R, Piplani M, Garg VK, Rao R, Lamba H.S. Formulation and Evaluation of Orally Disintegrating Tablets. Comparison of Natural and Synthetic Superdisintegrants. Scholars Research Library Der Pharmacia Lettre. 2011; 3(2): 407-18.

6. Bhowmik D, Chiranjib.B, jaiswal J, Dubey V, Chandira M. Fast dissolving tablet. A review on revolution of novel drug delivery system and new market opportunities. der pharmacia let 2009;1(2):262-76

7. V. N. Deshmukh. Mouth Dissolving Drug Delivery System: A Review. Int J PharmTech Res 2012;4(1):412-21 
8. Ashish P, Harsoliya M.S., Pathan J.K., Shruti S. A Review. Formulation of Mouth Dissolving tablet. Int J Pharm Clin Sci. 2011; 1(1): 1-8.

9. Kaur T, Gill B, Kumar S, Gupta G.D. Mouth dissolving tablets. A Novel approach to drug delivery. Int J Pharm Res. 2011;3(1):1-7.

10. Sagar A.K., Chaudhari P.S., Oswal R.J, Kshirsagar S.S, Antre R.V., Chorage T.V. Mouth dissolving tablets. an innovative technology. Int $\mathbf{J}$ App Bio and Pharma Sci. 2011;1(2):496-503.

11. Khan T, Nazim S, Shaikh S, Shaikh A, Khairnar A, Ahmed A. An Approach for rapid disintegrating tablet: A review. Int $\mathbf{J}$ Pharma Res Dev. 2011;3(3):170 - 183 .

12. Bhatt DA, Rane SI. Qbd approach to analytical RP-HPLC method development and its validation. Int J Pharm Pharm Sci. 2011; 3(1):179-187

13. Example QbD IR Tablet Module 3 Quality 3.2.P.2 Pharmaceutical Development [Internet]. FDA; 2012 Apr [cited 2014 April 27]. Available from: http://www.fda.gov/downloads/Drugs/Developme ntApprovalProcess/.

14. Somma R. Understanding Challenges to Quality by Design Using Quality by Design (QbD) in Designing Efficient, FDA Compliant Pharmaceutical manufacturing processes and facilities. [Internet]. FDA; 2009 Dec [cited 2014 April 27]. Available from:

http://www.pharmaqbd.com/wp-content/uploads /2011/05/Understanding-Challenges-to-Qualityby-Design.pdf

15. Belle GV, Fisher LD, Heagerty PJ, Lumley $T$. Biostatistics: A Methodology for the Health Sciences. Second Edition. New Jersey: A John Wiley \& Sons, Inc., Publication; 2004.

16. Hinkelmann K, Kempthorne O. Design and Analysis of Experiments. Advanced Experimental Design. Volume 2. New Jersey: A John Wiley \& Sons, Inc., Publication; 2005.

17. Myers JL, Well AD. Research Design and Statistical Analysis. Second Edition. New Jersey, London: Lawrence Erlbaum Associates Publishers; 2003.

18. Armstrong NA. Pharmaceutical Experimental Design and Interpretation. Second Edition. London: CRC Press Taylor \& Francis Group; 2006.

19. Q8 Pharmaceutical Development : $\mathrm{ICH}$ guidelines. [Internet]. ICH Expert Working Group; 2009 Aug [cited 2014 April 21]. Available from:

http://www.ich.org/fileadmin/Public_Web_Site/IC H_Products/Guidelines/Quality/Q8_R1/Step4/Q8 _R2_Guideline.pdf

20. Guidance for Industry. Q9 Quality Risk Management: ICH guidelines. [Internet]. US FDA; 2006 June [cited 2014 April 28]. Available from:

http://www.fda.gov/downloads/Drugs/.../Guidanc es/ucm073511.pdf
21. Q10 Pharmaceutical Quality System : ICH guidelines. [Internet]. ICH Expert Working Group; 2008 June [cited 2014 April 21]. Available from:

http://www.ich.org/fileadmin/Public_Web_Site/IC H_Products/Guidelines/Quality/Q10/Step4/Q10_ Guideline.pdf. 